\title{
Synchronous Online Learning through Microsoft Teams at Tertiary Level: Academic English Course
}

\section{Thitirat Wichanpricha}

\author{
Department of Western Language, \\ Rajamangala University of Technology Lanna Tak, \\ 41/1 Phaholyothin Road, Moo 7 Mai-ngam Sub-district, \\ Muang District, Tak 630oo, Thailand
}

DOI: https://doi.org/10.36941/jesr-2021-o111

\begin{abstract}
As for a recent learning platform as synchronous online learning through Microsoft Teams (MS Teams) in Academic English course based on particular three learning domains, very few previous studies were conducted and explored in Thailand and Asia. Due to the unending epidemic of COVID-19, the pedagogy in EFL context at every level of educational institutes has to be shifted to an online approach that has never been implemented in Rajamangala University of Technology Lanna Tak (RMUTL Tak), Thailand. The current study has mainly addressed the research gap by determining underlying cognitive, affective, and behavioral aspects in synchronous online learning. Therefore, this paper aimed to investigate perceptions and difficulties of synchronous learning in Academic English course through MS Teams. Academic English skills are not only acquired during the early years of Thai educational system but also at tertiary level. RMUTL Tak has currently provided an Academic English course as a mandatory subject that every undergraduate student has to pass this course before graduation. Promoting synchronous learning to Academic English course allows students have greater learning motivation. In the study, two hundred and fifty four undergraduate students studied in three faculties comprising Business Administration and Liberal Arts, Engineering, and Sciences and Agricultural Technology at RMUTL Tak. They were all enrolling in an Academic English course in the first semester, academic year 2020. Additionally, an online questionnaire including twenty one items and one open-ended question was employed in the study. All obtained data was analyzed quantitatively and qualitatively. The findings revealed that most of the participants have positively perceived synchronous learning as their fruitful online platform. Nonetheless, it was found that poor internet signal was considered as a dominant factor preventing them from learning online.
\end{abstract}

Keywords: synchronous online learning, students' perceptions, learning domains

\section{Introduction}

\subsection{Background of the study}

Online learning has been increasingly adopted as an instructional tool in the education industry, particularly in ESL and EFL contexts, over several years (Agung, Surtikanti \& Quinones, 2020). Online learning has brought many productive advantages to English language learners. They can get involved in either asynchronous or synchronous learning platforms to enhance English language abilities (Bailey \& Lee, 2020). As for synchronous learning, learners are able to deal with online 
lessons anywhere at a scheduled time. (Xia, Fielder \& Siragusa, 2013). Hence, synchronous learning environment can increase more flexibility in ESL and EFL learning.

As a result of the Corona Virus 2019 (COVID-19) spread, the pandemic consequences have caused concerns for people across the globe because it directly affected the quality of life, economics, trading, and educational institutes since early 2020. Many countries have announced strict precautions, including state lockdown regulation, to reduce the virus's spread for several months. This has resulted in the closure of academic institutions at all levels. By this virus epidemic, the conventional teaching method has forced to transition to the so-called 'new normal' platform, namely online classroom. According to the regulated practices upon the social distancing policy, the residents must stay home, so the increase of new cases would be slightly declined. In other words, both teachers and students are expected to handle their responsibilities working from home and learning online instead. Online learning and synchronous learning have recently been one of other possible practical teaching approaches not only in primary and secondary levels but also in higher education during COVID-19 pandemic (Ajmal, Alrasheedi, Keezhatta \& Yasir, 2020).

According to the current coronavirus 2019 (COVID-19) outbreak, the number of new cases has dramatically increased due to the arrival of illegal migrant workers (The Nation, 2020). The scenario turned out even more severe when positive cases were detected in almost every province in Thailand. Consequently, the Ministry of Higher Education, Science, Research and Innovation has announced the 'new normal' teaching approaches, namely synchronous online learning, to accommodate those study-from-home students in compliance with state precaution policy. Tak Province has been considered a risk area since it shares a borderline to Myanmar for 93.1 kilometers. Nonetheless, previous studies affirm that the shift of the onsite approach to online learning seems to be forceful. However, it is essential to continue language learning procedures more successfully than usual (Bao, 2020; Halim, Hashim \& Yunus, 2020; Hodges, Moore, Lockee, Trust \& Bond, 2020). Also, the study of Agung et al. (2020) underlined that online platforms frequently implemented in Southeast Asian countries are Microsoft teams (MS Teams), Zoom, Google Classroom. It is a fundamental challenge to all educators whether their education services rely on the stability of internet networks, fast-operated devices, and more effective well-planned content instead of the conventional approach.

Rajamangala University of Technology Lanna Tak (RMUTL Tak), a regional university located in the northern part of Thailand, has provided various programs at tertiary level in four faculties comprising Faculty of Engineering, Faculty of Business Administration and Liberal Arts, Faculty of Sciences and Agricultural Technology, and Faculty of Fine Arts and Architecture. Because of the widespread COVID-19 at domestic scale, RMUTL Tak has stipulated teaching method in synchronous online learning using MS Teams for fifteen consecutive weeks or four months. According to Glossary of Education Reform (2014), synchronous learning is defined as the forms of instruction, education, and learning management that are executed simultaneously without sharing the same venue. It is commonly applied to various digital forms and online learning that students master their lessons from teachers in real-time, such as live chat, online discussions, interactive webinars, and lectures that are synchronously broadcast at the same time they delivered. Those could all be considered as the forms of synchronous learning. The outbreak of COVID-19 has resulted in switching traditional classroom to online platform. RMUTL Tak students have to eventually learn online. Academic English skills are not only acquired during the early years of Thai educational system but also at tertiary level (Tananuraksakul, 2016). RMUTL Tak has currently provided an Academic English course (GEBLC103) as one of other compulsory courses that every undergraduate student has to pass this course before graduation. Regarding objectives of Academic English course, students should be able to broaden academic vocabulary, to practice English listening, speaking, reading, writing skills and to give presentations in academic contexts. Academic vocabulary has significantly been fundamental knowledge to enhance learners' target language skills particularly learning English for Academic purposes (EAP) as it is commonly found in a wide range of academic texts of different fields of study (Wiriyakarun, 2018). The optimal academic lexical threshold is set at 8,ooo word families and the minimal threshold is set at 4,00o - 5,00o word families (Agernäs, 2015; Laufer \& Ravenhorst-Kalovski, 
2010). The optimal threshold is established by defining the term adequate comprehension as "can read academic material independently" and "functional independence in reading. If adequate comprehension instead is interpreted as "reading with some guidance and help", then the minimal threshold is sufficient (Laufer \& Ravenhorst-Kalovski, 2010).

Promoting synchronous learning to Academic English course allows students have greater learning motivation. Szeto (2015) suggested that the combination of synchronous learning has become popular and has obtained much attention in undergraduate programs. The guidance on Microsoft Teams (MS Teams) utilization would motivate students in synchronous learning in three critical learning perspectives: cognitive, affective, and behavioral engagement (Abidin, PourMohammadi \& Alzwari, 2012; Louwrens \& Hartnett, 2015). The transformation to the new education platform and exciting teaching techniques can challenge students' online learning during such unfavorable circumstances.

Therefore, the pandemic of COVID-19 has brought several changes to both educators, learners in adopting and applying a synchronous learning approach to their courses. Students could be able to experience other kinds of learning online platforms during the COVID-19 restriction and regulation. This is why the current study investigates learners' perceptions towards synchronous learning, focusing on three learning domains, together with some possible barriers that occurred along with a fifteen-week experiment. This study will lead the educators to explore how to redesign and rethink conventional curriculum and instructional methods to other challenging online learning approaches. The findings of the study will be an ultimate guideline for choosing more suitable learning platform for English language courses in the future.

\section{Review of Literature}

\subsection{Synchronous online learning}

The advancement of ICT tools and technology in language learning has allowed students to learn anywhere and anytime. There are two types of flexible learning modes, namely synchronous learning and asynchronous learning. Synchronous learning occurs when the teacher connects with students with a set class schedule from a remote classroom in real-time (Yang, Yu, \& Chen, 2019). This means that the instructor and classmates can interact in a specific virtual place at a set time. Standard synchronous online learning methods include teleconferencing, live chatting, live-streamed lectures, and video conferencing that must participate in real-time (Bestschools, 2021).

Nevertheless, asynchronous learning allows students to learn on their own schedule, within a certain timeframe. They can access and complete lectures, readings, homework and other learning materials at any time during a one- or two-week period. Online asynchronous classes include short videos teaching key concepts that you can watch again, if it is necessary. In certain classes, students can also complete homework assignments and receive immediate feedback, as opposed to waiting for instructors to grade them (Carr, 2012; Scheiderer, 2020).

Additionally, synchronous learning means that although students will be learning from a distance, they will virtually get involved in a class session each week, at the same time as their instructor and classmates (Scheiderer, 2020). Online synchronous learning does not always take the form of a live lecture or an instructor-led discussion. Sometimes, students will lead the discussions themselves or give their own presentations to classmates. In an online class, group works do not go away, it just looks a bit different (Scheiderer, 2020). In synchronous learning, students are allowed to handle audio communication with instructors via video conferencing. It is defined as the transmission of video, audio, and data collaboratively and combines two or more ends through a communication line (Gough, 2006). Some instructors will raise challenging topics to students, who have to come up with answers first as a small group and as a whole class afterwards. Furthermore, Motamedi (2001) suggested that video conferencing systems' learning outcomes would be successful based on the technology used and affect the quality of learning and the level of interaction between 
teachers and students. More importantly, fostering students to participate in the procedure intentionally is essential in synchronous online learning.

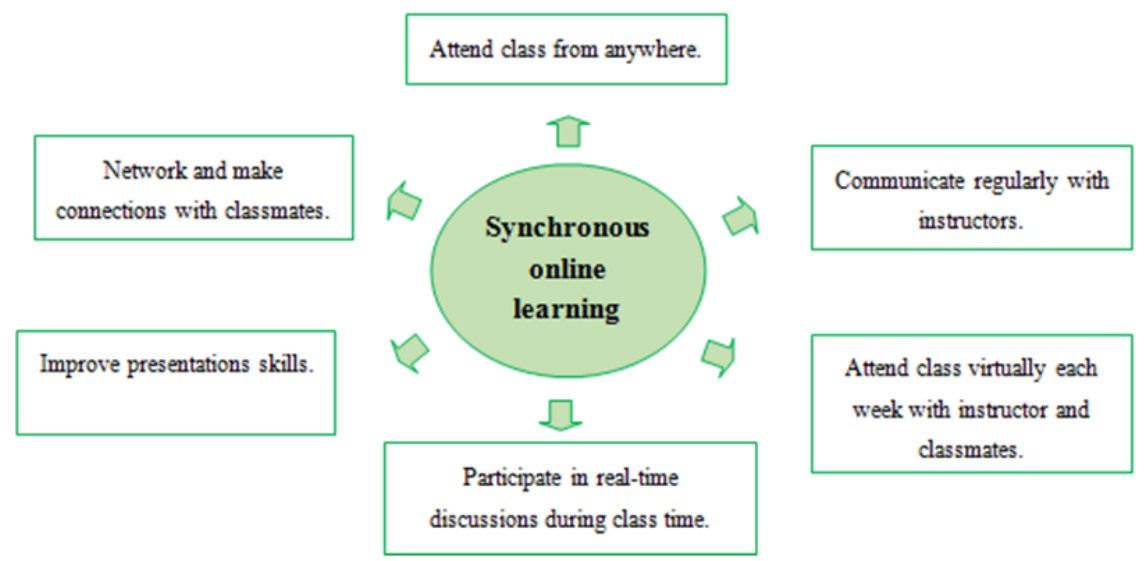

Figure 1: Synchronous online learning (Scheiderer, 2020)

\subsection{Students' perceptions towards synchronous online learning}

EFL students are likely to possess diverse learning styles resulting in having different opinions and perspectives towards online learning employing technology as an online medium of communication between teachers and students at any place at the same time (Mansor \& Ismail, 2012). Their study indicated that respondents who were Malaysian undergraduate students from the Faculty of Engineering had positive perceptions towards online learning effectiveness. There was no significant relationship to online learning of different respondents with various learning styles. Therefore, learning styles have not influenced the perceptions of engineering students when learning online. AlJarf (2007) determined that online learning was focusing on teaching vocabulary to EFL undergraduate students. It manifested that utilizing technology as an additional material apparently motivated and enhanced their vocabulary learning. In addition, the study of Shukri, Nordin, Salleh, Raidzwan and Ahmad (2020) traced the perception of students who were employing Zoom Cloud and Microsoft Teams as ICT tools in synchronous learning. The results suggested that EFL learners perceived online learning was very beneficial in attaining their learning objectives. In contrast, they honestly thought that a traditional teaching approach in the classroom was more effective than online learning.

Correspondingly, several existing studies revealed results contributing to students' perceptions in terms of both advantages and disadvantages of synchronous online learning during COVID-19 pandemic (Adara \& Najmudin, 2020; Agung et al., 2020; Ajmal et al., 2020; Allo, 2020; Baber, 2020; Bailey \& Lee, 2020; Harrison, 2021; Khafaga \& Shaalan, 2021; Karataş \& Tuncer, 2020; Ma, 2020; Mahyoob, 2020; Rahiem, 2020). Karataş \& Tuncer's (2020) findings reported that students positively perceived online learning as a productive and practical tool to broaden four English skills comprising listening, speaking, reading, and writing. They could also improve their learning, get timely feedback from teachers and classmates, and become more confident in doing better through synchronous online flipped method (Ma, 2020; Ajmal et al., 2020). In addition, students expressed that online learning was fruitful and individual assignments have been anticipated to happen (Allo, 2020). On the contrary, there might be specific obstacles of employing synchronous learning in EFL online classrooms. As for Ma's (2020) study, his results revealed that some Chinese students felt learning in traditional face-to-face classrooms was greater than online platforms. It might be because they could 
not have eye contact with other classmates when they shared their opinions and answers to particular online exercises. They could not concentrate on the synchronous online lessons due to family members talking and getting around when learning online at home ( $\mathrm{Ma}, 2020)$. Other online learning difficulties have been investigated by Ajmal et al. (2020) and Mahyoob (2020). Two studies recommended that accessibility of the internet was poor and limited. It, therefore, demotivated Pakistani learners to enhance their English skills.

Moreover, the instructors lacked internet and computer literacy dealing with technology-based teaching. Furthermore, some Turkish students were unable to afford any electronic devices to learn online, especially computers and some unsuitable learning environments prevented them from paying attention to online education (Karataş \& Tuncer, 2020; Mahyoob, 2020). Similarly, Filipino students' perceptions towards online learning in the remote area examined by Agung et al. (2020) affirmed that they were likely to get involved in a typical classroom rather than online education. An unreliable internet connection was still a dominant factor influencing students' achievement of online learning. They required some friendlier online platforms, so their participation could increase.

\subsection{Learning domains}

The current study basically employed three learning domains: cognitive, affective, and behavioral domains, to examine participants' perceptions using online questionnaire after participants have already participated in Academic English course through synchronous learning within fifteen weeks.

Christensen, Anakwe, and Kessler (2001) stated that the cognitive domain involved developing mental skills and acquiring knowledge of individuals and involved six categories: application; knowledge; synthesis; comprehension; analysis, and evaluation. Knowledge contains learners' ability to recall information or data. This was followed by comprehension that assessed the learner's ability to understand the meaning of what was known. It also referred to how individual learners cope with their learning style, such as understanding complicated ideas (Fredricks, Blumenfeld \& Paris, 2004; Harris, 2008; Louwrens \& Hartnett, 2015). It was defined by deep, strategic, focused thinking. Students cognitively regulated their learning by planning, monitoring, and reviewing their learning process. Feng and Chen (2009) suggested that learning process is a sensitive process influenced by various emotional factors in the affective domain.

These factors occurred when students reacted to class assignments, teachers, classmates, and learning (Abidin et al., 2012; Gibbs \& Poskitt, 2010). The affective domain also referred to attitude and interest towards learning. An optimal atmosphere of learning has also played a crucial role in affecting students' emotions (Shu, Zhao \& Wan, 2012). The behavioral domain dealt with the way students behaved and responded to particular conditions (Kara, 2009). The behavioral domain also involved students' reactions to course requirements, rules, and how they meet teacher's expectations (Gibbs \& Poskitt, 2010; Harris, 2008).

Regarding previous studies of three learning perspectives, Abidin et al. (2012) investigated Libyan students' attitudes towards learning English. Their results indicated that participants had negative attitudes towards English since they have not realized English's significance. Thus, they only undertook it as a compulsory course. Nevertheless, Louwrens and Hartnett's (2015) study considered students' engagement when they learned online in terms of three learning domains. Students in the study behaviorally participated in all activities. They gave and received feedback in their classmates' critiques as cognitive engagement, and they emotionally perceived online activities as enjoyable and fun.

Similarly, Sari and Rahmah (2019) determined the correlation of virtual discussion with cognitive, affective and psychomotor aspects of one hundred and ten Indonesian students. Their findings revealed that the virtual discussion has had strong correlation in all three domains and almost all significant values have been positive. Orfan's (2020) study was conducted to examine the cognitive, affective and behavioral attitudes of Afghan non-English major undergraduate students towards learning English. Students have positive cognitive, affective, and behavioral attitudes 
towards learning English. However, there was not a statistically significant difference in the attitudes of students by their age, gender, first language and field of study.

According to several previous studies mentioned earlier, their results have obviously provided benefits and barriers of handling a recent learning platform as synchronous online learning in EFL online classrooms. Nonetheless, very few prior studies were conducted and determined in three primary learning domains in online learning in Thailand and Asia. Due to the unending epidemic of COVID-19, the pedagogy in EFL context at every educational institute level has to be switched learning from an onsite to an online approach that has never been implemented in Rajamangala University of Technology Lanna Tak (RMUTL, Tak). The current study has mainly addressed the research gap by determining underlying cognitive, affective, and behavioral aspects in synchronous online learning engagement of Academic English course.

\section{Research Objectives}

1. To quantitatively explore students' perceptions towards synchronous online learning effectiveness of Academic English course through MS Teams in Thai EFL contexts during COVID-19 breakout.

2. To quantitatively examine a significant difference among three learning domains while students are learning Academic English through MS Teams.

3. To qualitatively investigate potential difficulties of synchronous online learning in Academic English course through MS Teams in the midst of COVID-19 spreading.

\section{Research Questions}

1. To what extent do students perceive synchronous learning as an online learning platform in Academic English course through MS Teams during COVID-19 pandemic in Thai EFL contexts?

2. Is there a significant difference among three learning domains while students are learning Academic English through MS Teams?

3. What possible difficulties do students encounter during synchronous online learning in Academic English course through MS Teams amid the expansion of COVID-19?

\section{Methodology}

\subsection{Research Design}

The design of the present study was an exploratory research method combining quantitative and qualitative data. A modified questionnaire, has included twenty-one items underlying cognitive, affective, and behavioral perspectives, was employed to gather quantitative data. Apart from quantitative data from rating scale in the questionnaire, the quantitative and qualitative data derived from participants' opinions in one open-ended question were counted. The questionnaires have been contributed to all participants online at the end of Academic English course ( $15^{\text {th }}$ week). The study was conducted fifteen weeks in the first semester of academic year 2020.

\subsection{Participants of the Study}

The present study participants were undergraduate students of Rajamangala University of Technology Lanna Tak (RMUTL Tak) studying in three faculties: Faculty of Engineering, Faculty of Business Administration and Liberal Arts, and Faculty of Science and Agricultural Technology. All of them, 19-22 years of age, have enrolled in a compulsory English course titled Academic English. The population of the study has entirely been seven hundred and fifty. They have been ascertained by the 
formula to calculate sample size designed by Krejcie and Morgan (1970). The sample size was two hundred and fifty-four participants, which were selected by purposive sampling. The sample group agreed to participate in the study by responding to the consent form of agreement online.

\section{$5 \cdot 3$ Instrument}

The study employed a questionnaire as a research tool consisting of two parts: part I included students' perceptions towards synchronous online learning in Academic English course through MS Teams that have consisted of twenty one items in total. Part II comprised one open-ended question related to students' opinions on barriers occurred while students were learning online through MS Teams during fifteen weeks.

\subsubsection{Questionnaire of students' perceptions}

Twenty-one questionnaire items were modified from Abidin et al. (2012) based on three main domains: cognitive, affective, and behavioral, and each domain question contained seven items. All items of the questionnaire were designed on Microsoft Forms, a survey administration software. The questionnaire was translated into Thai to help participants clearly understand all questions. The items were created on a Likert scale response using a five-interval scale of strongly agree, agree, undecided, disagree strongly disagree. The open-ended question was, "What potential difficulties did you encounter when learning Academic English course through MS Teams?" For their opinions, participants were required to express their reflection in Thai.

\subsubsection{Validity of the questionnaire}

To investigate the validity of the questionnaire, it was given to three English language instructors specializing in teaching English and research methodology at Rajamangala University of Technology Lanna Tak. The content of twenty-one items in part I and the open-ended question in part II were considered by the Index of Item-Objective Congruence (IOC) (Tuntavanitch \& Jindasri, 2018) in order to determine the contents of the questionnaire related to the objectives of the study underlying three learning aspects. According to the content, the validation of the questionnaire in part I and part II were 0.85 and 0.83 respectively, which were considered acceptable.

\subsubsection{Reliability of the questionnaire}

The questionnaire was tried out with thirty undergraduate students majoring in Civil Engineering, and they have enrolled in Academic English course at RMUTL Tak. To ascertain the reliability of the questionnaire, Cronbach's alpha coefficient was used to measure its reliability. The result was significantly 0.88 , which means that the questionnaire was reliable.

\subsection{Data Collection}

The procedures of data collection were as follows:

- The target participants enrolled in the Academic English course. This compulsory English course focused on developing four English skills: listening, speaking, reading, and writing and participants got involved in all online lessons simultaneously as teachers' schedule in fifteen weeks.

- The researchers made an appointment with English instructors who have currently taught Academic English course to distribute a survey link and QR code for accessibility of the constructed online questionnaire to two hundred and fifty four target participants at the 
end of an online lesson in week fifteen.

- Participants were informed of the study's purposes, and then they responded to an individual consent form before responding online questionnaire.

\subsection{Data Analysis}

The obtained data of participants' perceptions towards synchronous online learning was quantitatively analyzed as well as difficulties of synchronous online learning were qualitatively classified into particular themes.

\subsubsection{Quantitative Data}

The collected data was analyzed by employing Statistic Package for the Social Sciences (SPSS): mean $(\bar{x})$ and the standard deviation (S.D.). The results of participants' perceptions were transformed as the mean score of each item followed by Charernnit, K., Alhourani, A. Q., Arcinas, M. M., \& Velasco, L. G. (2021) and interpreted in five primary categories of 4.20-5.00-Highly Positive (strongly agree), 3.404.19-Positive (agree), 2.60-3.39-Neutral (undecided), 1.80-2.59-Negative (disagree) and 1.00-1.79Highly Negative (strongly disagree). In addition, a paired samples t-test was used to investigate a significant difference among three learning domains.

\subsubsection{Qualitative Data}

As for personal opinions in terms of synchronous online learning difficulties in Academic English course through MS Teams, content analysis (Strauss \& Corbin, 1990) was employed to analyze all written responses of two hundred and fifty four participants. The repeated keywords were counted to develop coding. Ultimately, they were thematically categorized into five themes adapted by Creswell and Poth's theoretical notion (2016). Every single theme was presented by frequency and percentage of key phrases in responses.

\section{Results}

\subsection{Quantitative Results}

\subsubsection{Results of students' perceptions towards Academic English course learning through MS Teams}

Obtained data according to twenty-one items of the questionnaire was quantitatively analyzed utilizing mean $(\overline{\mathrm{x}})$ and standard deviation (S.D.). The findings below were fundamentally based on three language learning domains: cognitive, affective, and behavioral domains.

\subsubsection{Cognitive domain}

The data interpreted the results of the cognitive domain. The study focused on how participants perceived English skills improvement while learning Academic English courses through MS Teams. The seven items' data was analyzed carefully to get understandable results throughout the entire statement, as in table 1. 
Table 1: Perceptions of synchronous online learning through MS Teams under cognitive domain ( $\mathrm{n}=254)$

\begin{tabular}{|c|c|c|c|}
\hline Statements & $\overline{\mathrm{x}}$ & S.D. & $\begin{array}{l}\text { Descriptive } \\
\text { Value }\end{array}$ \\
\hline $\begin{array}{l}\text { 1. I personally improve my English skills (listening, speaking, reading, and writing) when } \\
\text { learning Academic English through MS Teams. }\end{array}$ & 3.87 & 0.770 & Agree \\
\hline 2. I understand the content more when learning Academic English through MS Teams. & 3.72 & 0.860 & Agree \\
\hline 3. I can gain more Academic English vocabulary & 3.81 & 0.794 & Agree \\
\hline $\begin{array}{l}\text { 4. I believe that learning Academic English through MS Teams is as effective as learning in the } \\
\text { regular classroom. }\end{array}$ & 3.41 & 1.092 & Agree \\
\hline 5. I think learning Academic English anywhere through MS Teams becomes more convenient. & 4.08 & 0.896 & Agree \\
\hline 6. I think learning Academic English through MS Teams draws my attention. & 3.52 & 1.102 & Agree \\
\hline 7. I believe that learning Academic English through MS Teams makes me think more critically & 3.56 & 0.942 & Agree \\
\hline Overall & 3.72 & 0.797 & Agree \\
\hline
\end{tabular}

Table 1 shows the results on perceptions of Academic English course learning in terms of cognitive domain. Participants have been satisfied with synchronous online learning at a positive rating $(\overline{\mathrm{x}}=$ 3.72; S.D. $=0.797)$. The findings revealed that item 5 got the highest mean score $(\overline{\mathrm{x}}=4.08$; S.D. $=$ o.896), and they believed that it was more beneficial in learning Academic English in any place through MS Teams. Moreover, most students mostly felt sure that learning Academic English through MS Teams improved their English skills as in item $1(\overline{\mathrm{x}}=3.87$; S.D. $=0.770)$. Furthermore, they could broaden academic English vocabulary when learning through MS Teams in item $3(\overline{\mathrm{x}}=$ 3.81; S.D. $=0.794)$. With regard to item 2, they thought that they had a better understanding of academic content while learning Academic English course through this platform $(\overline{\mathrm{x}}=3.72$; S.D. $=$ o.860). Likewise, they realized that learning Academic English through MS Teams has allowed them to think more critically in item $7(\overline{\mathrm{x}}=3.56$; S.D. $=0.942)$ and enabled them more attention in items 6 $(\overline{\mathrm{x}}=3.52$; S.D. $=1.102)$. Lastly, they moderately concurred that online learning through MS Teams was as productive as learning in a typical classroom in item $4(\overline{\mathrm{x}}=3.41$; S.D. $=1.092)$.

\subsubsection{Affective domain}

The affective perspective's results present seven items in table 2 related to how participants felt during learning Academic English through MS Teams.

Table 2: Perceptions of synchronous online learning through MS Teams under affective domain $(\mathrm{n}=254)$

\begin{tabular}{|c|c|c|c|}
\hline Statements & $\overline{\mathrm{x}}$ & S.D. & $\begin{array}{c}\text { Descriptive } \\
\text { Value }\end{array}$ \\
\hline 8. I become more interested in Academic English lessons when learning through MS Teams. & 3.58 & 0.949 & Agree \\
\hline 9. I like learning Academic English through MS Teams than the traditional method. & 3.51 & 1.148 & Agree \\
\hline 10. Learning Academic English through MS Teams is interesting. & $3 \cdot 71$ & 1.048 & Agree \\
\hline 11. I enjoy doing online activities through MS Teams. & 3.70 & 0.973 & Agree \\
\hline 12. I become more confident in speaking English when learning Academic English through MS Teams. & 3.82 & 3.312 & Agree \\
\hline 13. Giving a group presentation in English through MS Teams challenges me. & 3.80 & 0.950 & Agree \\
\hline 14. I am proud of myself when I can give correct answers through MS Teams. & 3.87 & 0.907 & Agree \\
\hline Overall & 3.73 & 0.998 & Agree \\
\hline
\end{tabular}

Table 2 illustrates the results of perceptions according to affective domain. Most participants were satisfied by all the statements at a positive level $(\bar{x}=3.73$; S.D. $=0.998)$. For item 14, they mostly agreed that they were proud of themselves when giving the correct answers through MS Teams $(\overline{\mathrm{x}}=$ 3.87; S.D. $=0.907)$. Regarding item 12, they become more confident in speaking in English through MS Teams $(\overline{\mathrm{x}}=3.82$; S.D. $=3.312)$. Apart from this, they believed that contributing a group 
presentation in English through MS Teams challenged them a lot in item 13 ( $\bar{x}=3.80$; S.D. $=0.950)$. Likewise, they significantly concurred that they were interested and enjoyed getting involved in online activities while learning Academic English through MS Teams in items 10 ( $\bar{x}=3.71$; S.D. = 1.048) and followed by item 11 and $(\overline{\mathrm{x}}=3.70$; S.D. $=0.973)$. They also became more interested in academic lessons and preferred studying the Academic English through MS Teams presented in items 8 and $9(\bar{x}=3.58$; S.D. $=0.949$ and $\bar{x}=3.51$; S.D. $=1.148)$.

\subsubsection{Behavioral domain}

The following illustration displays the last seven statements concerning teachers' and students' interaction and their reaction while learning Academic English course through MS Teams. The data can be seen in table 3 .

Table 3: Perceptions of synchronous online learning through MS Teams under behavioral Domain $(\mathrm{n}=254)$

\begin{tabular}{|c|c|c|c|}
\hline Statements & $\overline{\mathrm{x}}$ & S.D. & $\begin{array}{l}\text { Descriptive } \\
\text { Value }\end{array}$ \\
\hline 15. I can work in pair or a group when learning Academic English through MS Teams. & 3.70 & 0.964 & Agree \\
\hline 16. I can share more opinions in Academic English lessons through MS Teams. & 3.72 & 0.969 & Agree \\
\hline 17. I am able to adjust myself to engage in Academic English lessons through MS Teams. & 3.51 & 1.066 & Agree \\
\hline $\begin{array}{l}\text { 18. I have a chance to practice English speaking in a role-playing and presentation with friends through } \\
\text { this platform. }\end{array}$ & 3.69 & 0.943 & Agree \\
\hline 19. I can review previous lessons independently through MS Teams. & 3.98 & 0.906 & Agree \\
\hline 20. I am able to interact with teachers and friends when learning Academic English lessons through MS Teams. & 3.86 & 0.943 & Agree \\
\hline 21. I can concentrate more on reading Academic English passages through MS Teams. & $3 \cdot 52$ & 1.062 & Agree \\
\hline Overall & 3.69 & 0.877 & Agree \\
\hline
\end{tabular}

Notes: 4.20-5.00-Highly Positive (strongly agree), 3.40-4.19-Positive (agree), 2.60-3.39-Neutral (undecided), 1.80-2.59-

Negative (disagree) and 1.0o-1.79-Highly Negative (strongly disagree)

As shown in table 3, participants have positively perceived that learning Academic English through MS Teams has been constructive platform in terms of behavioral domain $(\overline{\mathrm{x}}=3.69$; S.D. $=0.877)$. In item 19, most of them confidently concurred that they could review the previous lessons independently through MS Teams $(\overline{\mathrm{x}}=3.98$; S.D. $=0.906)$. Moreover, they could interact with teachers and friends when learning academic English lessons online in item $20(\bar{x}=3.86$; S.D. = o.943). Additionally, they significantly believed that they could share more personal opinions through MS Teams in item $16(\overline{\mathrm{x}}=3.72$; S.D. $=0.969)$. Regarding item 15 , they were able to work with their peers or in a team when learning Academic English through MS Teams $(\bar{x}=3.70$; S.D. $=0.964)$. Furthermore, they had opportunities to practice their speaking skill through role-playing and English presentation in item $18(\overline{\mathrm{x}}=3.69$; S.D. $=0.943)$. They could also concentrate more on reading through this platform in item $21(\overline{\mathrm{x}}=3.52$; S.D. $=1.062)$. Finally, they believed that they have been able to control themselves to Academic English lessons through MS Teams in item 17 ( $\bar{x}=3.51$; S.D. = 1.066).

\subsubsection{Comparison of three learning domains}

Table 4: Paired samples t-test of comparison of three learning domains

\begin{tabular}{|c|c|c|c|c|c|c|c|c|}
\hline \multirow{2}{*}{ Domain } & \multirow{2}{*}{$\mathrm{n}$} & \multirow{2}{*}{$\overline{\mathrm{x}}$} & \multirow{2}{*}{$\mathrm{SD}$} & \multicolumn{2}{|c|}{$95 \%$ Confidence Interval of the difference } & \multirow[b]{2}{*}{ t-value } & \multirow[b]{2}{*}{$\mathrm{p}$-value } & \multirow{2}{*}{ df } \\
\hline & & & & Lower & Upper & & & \\
\hline Cognitive & 254 & 3.72 & .797 & \multirow{2}{*}{-.101} & \multirow{2}{*}{.085} & \multirow{2}{*}{-.166} & \multirow{2}{*}{0.868} & \multirow{2}{*}{253} \\
\hline Affective & 254 & 3.73 & .998 & & & & & \\
\hline Affective & 254 & 3.73 & .998 & \multirow{2}{*}{-.036} & \multirow{2}{*}{.131} & \multirow{2}{*}{1.115} & \multirow{2}{*}{0.226} & \multirow{2}{*}{253} \\
\hline Behavioral & 254 & 3.69 & .877 & & & & & \\
\hline Cognitive & 254 & 3.72 & .797 & \multirow{2}{*}{-.037} & \multirow{2}{*}{.116} & \multirow{2}{*}{.116} & \multirow{2}{*}{0.313} & \multirow{2}{*}{253} \\
\hline Behavioral & 254 & 3.69 & .877 & & & & & \\
\hline
\end{tabular}


Table 4 exhibits the comparison of three learning domains comprising cognitive, affective and behavioral domains during consecutive fifteen weeks of learning Academic English though MS Teams. The results indicated that there was no statistically significant difference between cognitive domain and affective domain $\mathrm{t}=-0.166, \mathrm{p}=0.868,95 \% \mathrm{CI}(-0.10,0.09)$. The average score of two domains were similar at 3.72 and 3.73 respectively. In addition, the difference between affective and behavioral domains appeared insignificant $\mathrm{t}=1.115, \mathrm{p}=0.226 .95 \% \mathrm{CI}(-0.04,0.13)$ as well. The mean scores of the two were 3.73 and 3.69 respectively. By the same token, both cognitive and behavioral domains showed the similarity of the average scores at 3.72 and 3.69 respectively.

\subsection{Qualitative Results}

6.2.1 Results of participants' opinions on potential difficulties of learning Academic English through MS Teams

The study focused on participants' opinions on possible obstacles of synchronous online learning in Academic English through MS Teams during the spreading of COVID-19. All two hundred and fifty four participants have individually expressed their opinions to one open-ended question online. Content analysis was utilized and qualitatively analyzed. The repeated keywords were quantitatively counted into frequency and percentage. All key phrases in responses were categorized into five themes: problems of cognitive domain, affective domain, behavioral domain, internet connection and online program, and electronic devices, which were illustrated in the table 5 .

Table 5: Participants' opinions on barriers of synchronous learning in Academic English course via MS Teams $(n=254)$

\begin{tabular}{lcc}
\hline Themes and participants' opinions & Frequency of keywords & Percentage of keywords \\
\hline 1. Cognitive Domain & & \\
1.1 Preferring onsite to online learning & 130 & $51.18 \%$ \\
1.2 Being harder to understand inline lessons & 42 & $16.54 \%$ \\
\hline 2. Affective Domain & 5 & $1.97^{\circ} \%$ \\
\hline 2.1 Becoming drowsier & 28 & $11.02 \%$ \\
\hline 2.2 Turning to be apathetic & 4 & $1.57^{\%}$ \\
\hline 2.3 Lacking self-confidence & & \\
3. Behavioral domain & 22 & $8.66 \%$ \\
3.1 Being distracted & 28 & $11.02 \%$ \\
3.2 Lacking interaction & & \\
4. Internet connection and online program & 144 & $56.69 \%$ \\
4.1 Poor internet signal & 70 & $27.56 \%$ \\
4.2 Misunderstanding of dealing with MS Teams & & \\
5. Electronic devices & 9 & $3.54 \%$ \\
5.1 Lacking of electronic equipment & 6 & $2.36 \%$ \\
5.2 Broken earphones & 3 & $1.18 \%$ \\
5.3 Obsolete notebook & 1 & $0.39 \% \%^{* *}$ \\
5.4 Fuzzy webcam & & \\
$*$ *the highest percentage; ** the lowest percentage & & \\
&
\end{tabular}

As for table 5, poor internet connection and signal have totally been the main problem when participants were learning online $(56.69 \%)$. On the other hand, only one (o.39\%) participant pointed out that malfunctioned webcam was his/her synchronous learning difficulty.

According to theme 1, there have been two possible troubles based on cognitive domain, including preferring learning in a face-to-face classroom to an online platform and being harder to understand online lessons during COVID-19 breakout. It could be seen that more than half of them 
emphasized that Academic English learning should be taught in the traditional classroom (51.8\%). The lessons were less understandable and ineffective while learning Academic English through an online approach (16.54\%).

Regarding three problems underlying affective theme consisted of drowsiness, apathy, and lacking confidence, twenty eight participants thought that learning Academic English through MS Teams was demotivating (11.02\%). Moreover, some of them have become drowsy and apathetic when learning through this platform at $1.97 \%$ and $1.57 \%$ respectively.

With regard to theme 3, two barriers appeared in behavioral aspect: being distracted and lacking interaction with teachers and classmates. $11.02 \%$ of participants expressed that they did not have opportunities to interact with the teachers and/or their friends through MS Teams. Twenty two participants were not able to concentrate on online lessons (8.66\%).

Additionally, difficulties of internet connection and online program was shown in theme 4 . Over half of them have encountered the problem of unstable internet signals (56.69\%). One-fourth of them mentioned that MS Teams program has caused them some confusion about operating the online program properly (27.56\%).

The last theme was electronic devices' problems in learning Academic English through MS Teams: lacking electronic equipment, obsolete notebook, broken earphones, and fuzzy webcam. $3.54 \%$ of participants could not afford some electronic equipment by themselves. Their existing devices were unreliable and ineffective, especially microphone and earphones, notebooks, and webcam at $2.36 \%, 1.18 \%$, and $0.39 \%$ respectively.

\section{Discussion}

\subsection{Students' perceptions towards synchronous online learning through MS Teams}

The first research question determined perceptions' purposive sampling based on the current study while participants were learning Academic English through MS Teams according to three primary learning domains: cognitive, affective, and behavioral domains in fifteen consecutive weeks.

The findings manifested that most participants had positive perceptions of the use and program of MS Teams in synchronous online learning in Academic English course. Switching from conventional onsite instruction to online learning could motivate and encourage students to deal with online activities (Mansor \& Ismail, 2012; Khafaga \& Shaalan, 2021). Synchronous online learning has been meaningful and optimal to combine the latest technology into learning process during the COVID-19 pandemic. Students' positive perceptions have resulted in a possible trend of synchronous online learning continuation after the ending of COVID-19. This would perhaps predict the change of the educational system in the Thai EFL context and globally.

Correspondingly, it could be discussed that synchronous online learning can be an alternative constructive instructional method in EFL circumstances (Shukri et al., 2020). Participants strongly concurred that MS Teams has indeed been such a convenient online platform in learning Academic English course as for cognitive domain. They also believed that they could study everywhere and anytime with more stable and reliable internet connection. As reported by Yu and Chen's (2019), synchronous online learning can be tackled in real-time anywhere. It is a vital online tool for improving four English language skills comprising listening, reading, speaking, and writing. According to one of the findings' current study, although participants could not immediately ask questions or share answers during learning online, they have been able to leave some questions of the lessons via chat box of MS Teams anytime. Therefore, feedback and response have been provided to them by teachers later. Comparing to face-to-face classroom, students have lost opportunity to get simultaneous feedback from teacher owing to the fact that shy students cannot respond to class questions quickly (Wright, 2017). Nonetheless, those timid students have more chances and are allowed to contribute their answers through online chat box during synchronous learning.

Apart from this, participants were also able to broaden academic English vocabulary 
competence while learning online through MS Teams. The study of Al-Jarf (2007), whose finding claimed that employing technology in the classroom gained students' lexical items. In addition, synchronous online learning also drew Thai participants' attention in learning Academic English due to the fact that online platform have been relatively new for RMUTL Tak students. Therefore, they were keen on learning academic content online. In contrast, it seemed challenging to maintain Chinese students' interest in online learning owing to calls, chat messages, and neighbors' loud noise (Ma, 2020). Another exciting finding assured that synchronous online learning could promote critical thinking among Thai participants in Academic English course. It might be because they had to figure out answers to particular academic exercises online themselves more often. Also, they have had several chances of practicing decision-making and problem-solving through individual assignments, which have enhanced their critical thinking. That would be possibility of fostering other global EFL learners to heighten students' critical thinking practice through synchronous online learning.

Likewise, synchronous learning encouraged learners to proudly share their correct answers and give a group presentation in English confidently. These built up their learning challenge and motivation through MS Teams according to affective aspect. Compared to the studies of Ma (2020) and Ajmal et al. (2020), students were more confident in handling online assignments as well as they have done them better. Regarding behavioral domain, most participants were capable of revising the prior lessons independently through MS Teams and contributing more personal opinions through this platform. Interestingly, synchronous learning could continuously keep interaction with teachers and classmates. These were evidenced by empirical studies of Louwrens and Hartnett (2015) and Agung et al. (2020), modern technology played an essential role in students' positive attitudes and behavior. They could interact with their friends and teachers although they learned online at home or other remote places. They still have achieved their target language goals and particular online lesson successfully.

\subsection{Comparison of three learning domains}

The second research question considered a significant difference among three learning domains while learning Academic English through MS Teams.

Since analyzing the comparison of three main learning aspects by paired samples t-test, it can be noted that there was no statistically significant difference of three pairs, namely cognitive and affective aspects, affective and behavioral aspects as well as cognitive and behavioral aspects. The average mean scores of them appeared quite similar to each other. It has reflected that synchronous learning through the platform of MS Teams would similarly support participants in engaging in learning Academic English according to their thinking and recognition of what have been learned (cognitive domain), their feeling and emotion (affective domain) and their way of reaction and response to particular condition (behavioral domain). This agrees with Orfan's (2020) result that the overall attitude of Afghan students towards English in terms of cognitive, affective and behavioral aspects was positive. Nevertheless, the present finding contradicts the study conducted by Sari and Rahmah (2019) who reported that there was a negative significant value comparing cognitive domain and affective domain. The increasing of cognitive domain when dealing with virtual discussion is not followed by the increasing of affective domain.

\subsection{Opinions on potential obstacles of synchronous online learning through MS Teams}

The third research question investigated some potential difficulties of synchronous online learning in Academic English course through MS Teams. The findings reported five themes, including cognition, feeling, behavior, internet connection and online program, and electronic devices.

As specified by qualitative results, it could notably be seen that half of the participants preferred learning Academic English in a traditional classroom to MS Teams. This was quite different from quantitative obtained data referring to cognitive aspect that Thai participants perceived synchronous 
online learning as productive as learning in a typical way. However, they were more favorable face-toface classroom than online channel amid COVID-19 because the latest learning platform as MS Teams was relatively new for them, and they still have not understood how to operate the program very well.

Based on other synchronous online learning barriers, participants have never seen their peers' reactions while learning online. That has directly affected them in learning English with a lack of enthusiasm. The online classroom was less effective than the conventional instructional channel (Ajmal et al., 2020). Moreover, when they contributed their correct answers online, they did not have any eye contact with the rest of their classmates. It seems that they individually learned entire lessons without classmates' interactions and responses. Similarly, some of participants felt that learning Academic English through MS Teams was sometimes drowsy and apathetic when learning online in terms of students' affective aspect. It means demotivation has prevented them from English online learning. Lacking motivation was an online learning problem in mastering the target language (Adara \& Najmudin, 2020); Alqurashi, 2011). Compared to synchronous learning, the typical learning method has a more extraordinary learning atmosphere than an online platform.

Correspondingly, participants had fewer chances to interact with their teachers or even friends through MS Teams regarding behavioral aspect because of time constraint on online tasks. The teachers should provide them more time and opportunities to deal with peer or group assignments online and after lessons more often. Undoubtedly, poor internet signal seemed to be a significant problem that caused a considerable impact on the current study under synchronous online learning. It means that unless there is stable internet available at the place they are, they cannot catch up with the existing online lessons. This has reconciled with Mahyoob's (2020) recommendation that switching learning environments, unstable internet connection, and incompatible gadgets were demotivational factors affecting online learning during COVID-19 pandemic. The strength of internet signals and wellequipped electronic devices would promote and motivate students in language learning more effectively. In the long run, a reliable internet connection should be provided uninterruptedly to encourage students to master specific online lessons and learning materials anywhere. Hence, student's academic performance would be improved through synchronous online learning.

\section{Conclusion}

The present study aimed at investigating students' perceptions and difficulties of synchronous online learning in Academic English course through MS Teams during COVID-19 epidemic. Two hundred and fifty four undergraduate students were studying in three faculties comprising the Faculty of Business Administration and Liberal Arts, Faculty of Engineering, and Sciences and Faculty of Agricultural Technology at RMUTL Tak. They all enrolled in the Academic English course. Additionally, an electronic questionnaire including twenty one items and one open-ended question was employed in the study. Obtained data was analyzed quantitatively and qualitatively. In other words, quantitative data was transcribed by mean and standard deviation. Participants' opinions on difficulties of using MS Teams in Academic English learning gathered data qualitatively and quantitatively categorized into five themes: problems of cognitive, affective, behavioral dimensions, internet signal and online program, and electronic devices.

Participants' perceptions of Academic English course learning through MS Teams indicated that they positively perceived Academic English mastery. Students mostly believed that MS Teams was something that can be very useful and convenient anywhere else. They were also aware of improving English four skills while learning online and strengthened a great deal of academic vocabulary. They could think more critically on academic topics underlying cognitive aspect. Additionally, it could be noted that giving some correct answers and a group presentation in English through MS Teams have increased students' self-esteem and their pride in English learning achievement in terms of affective aspect. As for behavioral aspect, they still have had many chances to revise all previous lessons themselves, and they have firmly kept their participation and interaction with their friends and 
teachers while learning through MS Teams.

With regard to the comparison of three learning perspectives, there was no statistically significant difference among cognitive aspect, affective aspect and behavioral aspect. On account of similar mean scores at positive level, it can be concluded that an online platform as synchronous learning through MS Teams has been one of other constructive approaches supporting and encouraging students in involving in learning target language online underlying three main learning perspectives in academic context.

Notably, barriers of learning Academic English course through MS Teams assured that half of participants were likely to learn onsite rather than online platform as their learning preference. Other problems encountered only some of participants have become drowsy, apathetic, and less selfconfident while learning Academic English through MS Teams. Furthermore, internet signal strength was considered the dominant factor that prevented them from online learning. This might cause a massive impact on English learning in EFL context. Accessibility to electronic devices was certainly another obstacle. According to their reflections, very few participants could not afford notebooks, microphones, and/or webcam.

It could entirely conclude that synchronous online learning has been an additional fruitful and optimal pedagogical approach allowing students to master foreign language skills online amid the breakout of COVID-19. The new trend has led to the change of education industry in Thailand and across the world. The current study's findings have affirmed several advantages and certain disadvantages of promoting MS Teams to students at a tertiary level in unexpected conditions, particularly in remote area. Teachers and students would be able to continuously deal with their lessons online and meet their course objectives. It does not mean that online learning have totally been more effective than traditional classroom or vice versa. According to present study's results revealing some problems of synchronous online learning, it has suggested that online pedagogy can probably be skillfully incorporated into a regular face-to-face classroom if particular attention is provided to suitability of technology and materials. Teachers and students have to take responsibility to fully engage during online teaching and learning rather than seeing online lessons as something to avoid working or studying. Both online and regular classrooms should be implemented with the aim of delivering an interesting and motivating lessons to students. Educational institutes where demands for electronic devices, training the use of online program and how to integrate online methodology in language learning must be made available to teachers by their institutes. Reliable internet connection must also be provided especially in rural area. Bringing online technology, media and electronic textbook to English language classroom must be skilled, however, importance of faceto-face instruction with teachers should not be undermined.

Regarding concern over the limitations of the study, one of dominant difficulties of online learning is that there has not been consistent internet connection provided in a remote area. The university, RMUTL Tak, has encountered the problem of unstable internet signal when accessing online materials and educational websites. It has been impossible to completely switch traditional classroom to online platform in RMUTL Tak. However, it has been challenging and interesting to integrate online materials and assignments into face-to-face classroom. According to the present study, it has been conducted as an exploratory research approach employing questionnaire to collect data. It will gain more significant and more empirical findings if the study utilizes more research instruments, especially semi-structured interviews in focus groups of students and observation sheet. More importantly, a longitudinal study should be done quantitatively and qualitatively in two regular semesters or more to affirm the ongoing better results shed light on the possibility of combination of online learning and conventional face-to-face instruction to further EFL pedagogical implementation especially in remote area. 


\section{Acknowledgments}

I would like to express my gratitude to two hundred and fifty four undergraduate students at RMUTL Tak, Thailand responding to online questionnaire as well as English language instructors from the Department of Western Language and the Department of English for International Communication distributing the QR code of the online questionnaire to the target respondents. I would also be grateful to three English language experts for their expertise in research methodology on revising the questionnaire. Last but not least, a special thanks also to Assist. Prof. Dr. Sawitri Suwanaroa and Dr. Arunee Wongkhao who have provided the greatest advice of statistical data analysis and guidance of improving this research paper. The study would not have been successfully executed without all their exceptional participation and assistance.

\section{References}

Abidin, M. J. Z., Pour-Mohammadi, M., \& Alzwari, H. (2012). EFL students' attitudes towards learning English language: The case of Libyan secondary school students. Asian social science, 8(2), 119.

Adara, R. A., \& Najmudin, O. (2020). Analysis on the Differences in EFL Learners' Demotivating Factors after Covid 19 Pandemic. Ta'dib, 23(2), 225-236.

Agernäs, E. (2015). Vocabulary size and type goals in advanced EFL and ESL classrooms. A review of research on lexical threshold, lexical coverage, reading and listening comprehension. p.10-11.

Agung, A. S. N., Surtikanti, M. W., \& Quinones, C. A. (2020). Students' Perception of Online Learning during COVID-19 Pandemic: A Case Study on the English Students of STKIP Pamane Talino. SOSHUM: Jurnal Sosial Dan Humaniora, 10(2), 225-235.

ahiem, M. D. (2020). The emergency remote learning experience of university students in Indonesia amidst the COVID-19 crisis. International Journal of Learning, Teaching and Educational Research, 19(6), 1-26.

Ajmal, M., Alrasheedi, S., Keezhatta, M. S., \& Yasir, G. M. (2020). COVID-19 and online English Language Teaching: Students' Response and Feedback. Asian ESP Journal, 16(5.2), 39-56.

Al-Jarf, R. (2007). Teaching vocabulary to EFL college students online. Call-EJ Online, 8(2), 1-16.

Allo, M. D. (2020). Is the online learning good in the midst of Covid-19 Pandemic? The case of EFL learners. Jurnal Sinestesia, 10(1), 1-10.

Alqurashi, F. (2011). eLearning in EFL: Problems and solutions. Psychology of Language and Communication, 15(1), 107-116.

Baber, H. (2020). Determinants of Students' Perceived Learning Outcome and Satisfaction in Online Learning during the Pandemic of COVID-19. Journal of Education and e-Learning Research, 7(3), 285-292.

Bailey, D. R., \& Lee, A. R. (2020). Learning from experience in the midst of covid-19: benefits, challenges, and strategies in online teaching. Computer-Assisted Language Learning Electronic Journal, 21(2), 178-198.

Bao, W. (2020). COVID-19 and online teaching in higher education: A case study of Peking University. Human Behavior and Emerging Technologies, 2(2), 113-115.

Bates, T. (1995). Technology: Open learning and distance education. New York: Routledge.

Bestschools. (2021). Synchronous Learning vs. Asynchronous Learning in Online Education. Retrieved from https://thebestschools.org/magazine/synchronous-vs-asynchronous-education/

Carr, V. B. (2012). Asynchronous Learning. In: Seel N.M. (eds) Encyclopedia of the Sciences of Learning. Boston: Springer.

Charernnit, K., Alhourani, A. Q., Arcinas, M. M., \& Velasco, L. G. (2021). Cognitive and Attitudinal Effects of

Jigsaw Technique as a Collaborative Learning Strategy in Literature Teaching in the Philippines. Asian EFL Journal, 28(3.2), 267-285.

Christensen, E. W., Anakwe, U. P., \& Kessler, E. H. (2001). Receptivity to distance learnings the effect of technology, reputation, constraints, and learning preferences. Journal of Research on computing in education, 33(3), 263-279.

Creswell, J.W. \& Poth, C.N. (2016). Qualitative inquiry\& research design: Choosing among five approaches. (4). Thousand Oaks, CA: Sage.

Feng, R., \& Chen, H. (2009). An analysis on the importance of motivation and strategy in postgraduates English acquisition. English Language Teaching, 2(3), 93-97.

Fredricks, J. A., Blumenfeld, P. C., \& Paris, A. H. (2004). School engagement: Potential of the concept, state of the evidence. Review of educational research, 74(1), 59-109. 
Gibbs, R., \& Poskitt, J. (2010). Student engagement in the middle years of schooling (Years 7-10): A literature review. Wellington, New Zealand: Ministry of Education.

Glossary of Education Reform (2014). Synchronous Learning. Retrieved from https://www.edglossary.org/synchro nous-learning/

Gough, M. (2006). Video conferencing over IP: configure, secure, and troubleshoot. Rockland, MA: Syngress Publishing.

Halim, M. S. A. A., Hashim, H., \& Yunus, M. M. (2020). Pupils' motivation and perceptions on ESL lessons through online quiz-games. Journal of Education and E-Learning Research, 7(3), 229-234.

Harris, L. R. (2008). A phenomenographic investigation of teacher conceptions of student engagement in learning. The Australian Educational Researcher, 35(1), 57-79.

Harrison, M. F. (2021). An Investigation of the factors that Determines Student Satisfaction with EFL Online Classes. Asian EFL Journal, 28(1.2), 67-88.

Hodges, C., Moore, S., Lockee, B., Trust, T., \& Bond, A. (2020). The difference between emergency remote teaching and online learning. Educause Review, 27, 1-12.

Kara. (2009). The Jordanian Secondary Stage students Achievement in Reading comprehension according to their views towards Learning English as a Foreign Language. Journal of Human Sciences, 42, 1-36.

Karataş, T. Ö., \& Tuncer, H. (2020). Sustaining Language Skills Development of Pre-Service EFL Teachers despite the COVID-19 Interruption: A Case of Emergency Distance Education. Sustainability, 12(19), 1-34.

Khafaga, A. F., \& Shaalan, I. E. A. W. (2021). Mobile Learning Perception in the Context of COVID-19: An Empirical Study of Saudi EFL Majors. Asian EFL Journal, 28(1.3), 336-356.

Koppelman, H. \& Vranken, H. (2008). Experiences with a synchronous virtual classroom in distance education. ACM Sigcse Bulletin, 40, 194-198.

Krejcie, R.V. \& Morgan, D.W. (1970). Determining sample size of research activities. Educational and Psychological Measurement, 30, 607-610.

Laufer, B., \& Ravenhorst-Kalovski, G. C. (2010). Lexical threshold revisited: Lexical text coverage, learners' vocabulary size and reading comprehension. (p.25).

Louwrens, N., \& Hartnett, M. (2015). Student and teacher perceptions of online student engagement in an online middle school. Journal of Open, Flexible, and Distance Learning, 19(1), 27-44.

Ma, G. (2020). The Effectiveness of Synchronous Online Flipped Learning in College EFL Reading

Course During the COVID-19 Epidemic. Retrieved from https://assets.researchsquare.com/files/rs84578/v1/cccfed35-424c-4dd5-9727-bdd9853cdb40.pdf

Mahyoob, M. (2020). Challenges of e-Learning during the COVID-19 Pandemic Experienced by EFL Learners. Arab World English Journal (AWEJ), 11(4), 351-362.

Mansor, M. S. A., \& Ismail, A. (2012). Learning styles and perception of engineering students towards online learning. Procedia-Social and Behavioral Sciences, 69, 669-674.

Orfan, S. N. (2020). Afghan undergraduate students' attitudes towards learning English. Cogent Arts $\mathcal{E}$ Humanities, 7(1), 1723831.

Sari, I. D. P., \& Rahmah, T. H. (2019). Virtual discussion for EFL students establishing three domains: cognitive, affective, and psychomotor. International Journal for Educational and Vocational Studies, 1(3), $249-253$.

Scheiderer, J. (2020). What's the Difference Between Asynchronous and Synchronous Learning? Retrieved from https://online.osu.edu/resources/learn/whats-difference-between-asynchronous-and-synchronous-learning

Shu, F., Zhao, C., \& Wan, L. (2012). Enhancing online class student engagement through discussion. In International Conference on Web-Based Learning (pp. 349-354). Berlin, Heidelberg: Springer.

Shukri, A., Nordin, L., Salleh, F. I. M., Raidzwan, S. N. M., \& Ahmad, R. (2020). UniKL Students' Perception on Synchronous Learning Using ICT as Learning Tools to Learn English. Journal of Critical Reviews, 7(8), $793-796$.

Strauss, A., \& Corbin, J. (1990). Basics of qualitative research. Newbury Park: Sage publications.

Szeto, E. (2015). Community of inquiry as an instructional approach: What effect of teaching, social and cognitive presences are there in blended synchronous learning and teaching? Computer and Education, 81, 191-201.

Tananuraksakul, N. (2016). Blended e-learning as a requirement for teaching EFL in a Thai academic context. Teaching English with Technology, 16(4), 48-55.

The Nation. (2020). 11 illegal migrants detained in Mae Sot, two found to have high fever. Retrieved from https://www.nationthailand.com/news/30393788

Tuntavanitch, P., \& Jindasri, P. (2018). The Real Meaning of IOC. Journal of Educational Measurement Mahasarakham University, 24(2), 3-12.

Wiriyakarun, P. (2018). Examining Thai EFL learners' knowledge of academic English vocabulary. The Liberal Arts Journal, Mahidol university, 1(1), 119-132.

Wright, B. M. (2017). Blended learning: Student perception of face-to-face and online EFL lessons. Indonesian journal of applied linguistics, 7(1), 64-71. 
Xia, J. C., Fielder, J., \& Siragusa, L. (2013). Achieving better peer interaction in online discussion forums: A reflective practitioner case study. Issues in Educational Research, 23(1), 97-113.

Yang, J., Yu, H., \& Chen, N. S. (2019). Using blended synchronous classroom approach to promote learning performance in rural area. Computers $\mathcal{E}$ Education, 141, 103619, 1-13. 